\title{
THE COMBATING OF TUBERCULOSIS: HEALTH PERCEPTIONS, INTENTIONS AND VACCINATION OF CHILDREN
}

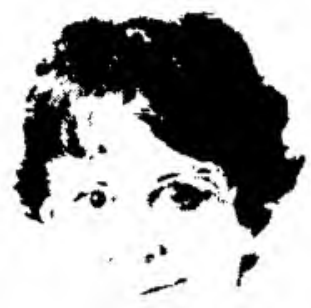

M. Steyn

\section{Mariana Steyn, Marlene Viljoen}

\section{Summary}

This study was part of a comprehensive research project undertaken at the request of the SANTA Health Education Committee to evaluate the tuberculosis guidance programme.

The aim of the research was to examine factors influencing black people's health perceptions and intentions concerning the combating of tuberculosis as well as vaccination of their children.

Data were collected by means of a questionnaire based on the Health Belief Model. The research was conducted in selected areas of the OFS, the Transvaal and Natal $(N=1$ 198).

It was found that factors indicating a greater degree of development of the individual (e.g. literacy) were positively associated with positive health perceptions such as that medical treatment can cure TB completely.

Some positive associations were also found between perceptions/modifying factors and intentions/vaccination. Indications were also found of an inability on the part of health personnel to influence the public positively.

\section{Opsomming}

Hierdie ondersoek vorm deel van 'n omvattende navorsingsprojek wat op versoek van die SANTV-gesondheidsvoorligtingskomittee onderneem is om die tuberkulose-voorligtingsprogram te evalueer.

Die doel met die studie was om ondersoek in te stel na faktore wat swartmense se gesondheidsoortuigings en-voornemens ten opsigte van tuberkulose-bestryding, asook die inenting van hul kinders beïnloed.

Data is deur middel van ' $n$ vraelys ingesamel wat gebaseer is op die Gesondheidsoortuigingsmodel. Die navorsing is in geselekteerde gebiede in die OVS, Transvaal en Natal $(N=l 198)$ uitgevoer.

Daar is gevind dat faktore wat 'n groter mate van ontwikkeling van die individu aandui (byvoorbeeld geletterdheid) positiewe verbande getoon het met positiewe gesondheidspersepsies, byvoorbeeld dat mediese behandeling tuberkulose kan genees. Enkele positiewe verbande is ook gevind tussen gesondheidspersepsies/modifiserende faktore en voornemens/inenting. Aanduidings is ook gevind van ' $n$ onvermoë aan die kant van gesondheidspersoneel om die gemeenskap positief te beinvloed.

\section{INTRODUCTION}

Tuberculosis (TB) is a significant health problem throughout the world. In South Africa the incidence varies between 100 150/100 000 (Glatthaar 1982: 37) and is particularly high $(200 / 100000)$ in the black population (Fourie, Townshend and Kleeberg 1986: 386). A lack of community involvement in the field of TB control contributes to this situation. A tuberculosis control programme has been developed that includes a guidance programme aimed at motivating the community to participate in case-finding, supervision and treatment at home, and improving socio-economic circumstances (Glatthaar 1982:39). This study was part of a comprehensive research project undertaken at the request of the SANTA
Health Education Committee to evaluate the tuberculosis guidance programme. The purpose of the study reported here was to establish the role in certain black areas of the factors posited by the Health Belief Model (HBM) in individual health perceptions, intentions to combat tuberculosis and previous vaccination of respondents' children.

\section{METHODS}

2.1 The model on which the study is based The HBM was used as basis for this study. The HBM was originally developed in the early fifties by Rosenstock, Hochbaum and Kegeles in order to identify factors which affect the individual's health behaviour. The basic suppositions of the HBM is that the individual will take steps to prevent illness if two health perceptions are held. Firstly, the person must believe that he is susceptible to an illness. Secondly, he must believe that the illness will have a reasonably serious impact on his life. If these two conditions prevail in the mind of the person, then the person must also believe that the benefits of a specific health-orientated action would outweigh the obstacles which stand in the way of action.

The probability that the individual will take the necessary steps is further influenced by a set of modifying factors, for instance demographic variables such as age and sex; sociopsychological variables such as reference group; and structural variables such as knowledge of the illness and previous experience thereof. 
A further set of variables, cues to action, is necessary to motivate the person to act. A cue can range from an insignificant to a fairly dramatic incident (Galli 1978:187 et seq. Becker et al. 1975:3 et seq. Rosenstock 1966:97 et seq. Pender 1982:46 et seq. Gochman 1972:286 et seq.).

The original model was adapted by various authors. Pender (1982:46 et seq.) for instance included two further health perceptions, namely a perception of the importance of health and a perception of control over health.

The research reported here was based on the original HBM including these two health perceptions put forward by Pender.

\subsection{Questionnaire}

The data were obtained by means of a pretested questionnaire which was compiled in collaboration with experts on TB and completed during interviews. The model as adapted for this study appears in Figure 1.

\subsection{Sample}

The research was conducted in the OFS, the fansvaal and Natal. The sample consisted of 1198 black respondents between the ages of 18 and 64 drawn randomly in six selected areas, three of which were guidance areas while the others were not. The study was undertaken in rural as well as urban areas.

\subsection{Analysis of the data}

It was decided not only to examine factors which influenced intentions and actual behaviour but also factors which influenced health perceptions. The logit model was used to test for associations between

a) modifying factors (demographic, sociopsychological, structural factors) and individual health perceptions, and

b) modifying factors, individual health perceptions, perceptions of obstacles and cues to action on the one hand and intentions to combat $\mathrm{TB}$ and vaccination of children on the other.

\section{T. RESULTS}

In order to facilitate presentation of the data only associations which are significant at the $10 \%$-level between the dependant and independant variables are discussed (details of the statistical analyses appear in Steyn 1988). Attention will be paid in the first instance to variables which played a signficant role in the five individual health perceptions. After that the variables which played a significant role in intentions and vaccination will be discussed.

\subsection{Individual health perceptions}

When associations between modifying factors and individual health perceptions are examined it is seen that there is no clear pattern. However, certain trends appeared and are summarized here:

\subsubsection{Perception of the importance of health}

A positive association was found between the ability to read well and a perception of health as important.
3.1.2 Perception of control over health Two questions were asked. As far as the first question was concerned, a positive association was found between the ability to read well and the perception that the individual can promote his own health. The results of the second question show positive associations between the ability to read well, urban residence and awareness of the $\mathrm{TB}$ emblem and the perception that the individual can reduce his own chances of contracting TB. Knowledge about TB also shows a predominantly positive association with this latter perception while attitudes towards the combating of TB show positive as well as negative associations.

\subsubsection{Perception of susceptibility to TB}

Positive associations were found between the ability to read well, age, and receiving information from the mass media on the one hand and a perception of a greater degree of susceptibility to TB on the other. Urban residence, receiving information from friends/relatives, and receiving information from health personnel show negative associations with this perception.

\subsubsection{Perception of the seriousness of TB} Three questions were asked about the effect TB would have on the respondents' health, work and family. Associations that were found were largely contrary to expectations.

A positive attitude towards the combating of TB shows a negative association with the perception that personal health would be seriously affected by TB. The ability to read well and urban residence, in interaction with awareness of the TB emblem, also show mainly negative associations with this perception.

The ability to read well, urban residence, receiving information from friends/relatives and knowledge of TB show negative associations with the perception that TB would affect the respondents' work seriously.

Urban residence and receiving information from friends/relatives also show negative associations with the perception that the family will be seriously affected if the respondent were to contract $\mathrm{TB}$.

\subsubsection{Perception of the benefits of medical treatment for TB}

There were positive associations between the ability to read well, residence in an experimental area, knowledge of TB, a positive attitude towards the combating of TB and awareness of the TB emblem on the one hand and the perception that medical treatment can cure TB completely on the other. However there was a negative association between information received from friends/ relatives and this perception

\subsection{Prevention of TB}

Although no clear pattern of associations were found between the independent variables and intentions to combat TB or vaccination of children, some trends became evident.

3.2.1 Intention concerning a suspected TB sufferer who does not receive treatment Both the perception that the individual can promote his own health and a positive attitude towards the combating of TB show positive associations with the intention to refer a suspected TB sufferer for treatment.

\subsubsection{Intention concerning a TB sufferer who does not take his medication}

Positive associations were found between the perceptions that a TB infection could have serious implications for personal health and for the family respectively and knowledge of TB on the one hand and the intention to either refer him for treatment or to supervise a TB sufferer who does not take his medication on the other. However the perception that a TB infection could have a serious effect on the work situation had a negative association with this intention.

\subsubsection{Intention concerning the suspicion} that the respondent himself may have $\mathrm{TB}$

The perception that the individual can reduce his chances of a TB infection, the perception that medical treatment can cure TB completely, awareness of the TB emblem and receiving information from the mass media show positive associations with the intention to seek professional advice if the individual should suspect that he has TB.

\subsubsection{Intention concerning the supervising of a TB sufferer's treatment}

Concern about personal health in general, the perception that medical treatment can cure a TB sufferer completely, knowledge of TB and receiving information from the mass media show positive associations with the willing ness to supervise a TB sufferer's treatment.

\subsubsection{Intention concerning the conceal- ment of a personal TB infection}

Concern about personal health in general, the perception that TB treatment is free of charge knowledge of TB and a positive attitude towards the combating of TB show positive associations with the intention not to conceal a TB infection. Again, receiving information from friends/relatives shows a negative association with this intention.

\subsubsection{Previous vaccination of children}

Vaccination of children is the dependent variable that shows the most frequent associations with the independent variables. The perception that the individual can reduce his chances of contracting TB, acquaintance with a TB sufferer and the perception that TB treatment is free of charge show positive associations with the previous vaccination of children. The perception that TB can seriously affect the work situation shows predominantly negative associations in interaction with other variables, with the vaccination of children.

Positive association also occurred between the ability to read well (three out of four interactions), urban residence (two out of three interactions), receiving information from friends/relatives, receiving information from health personnel, knowledge of TB and receiving information from the mass media on the one hand and vaccination on the other. 


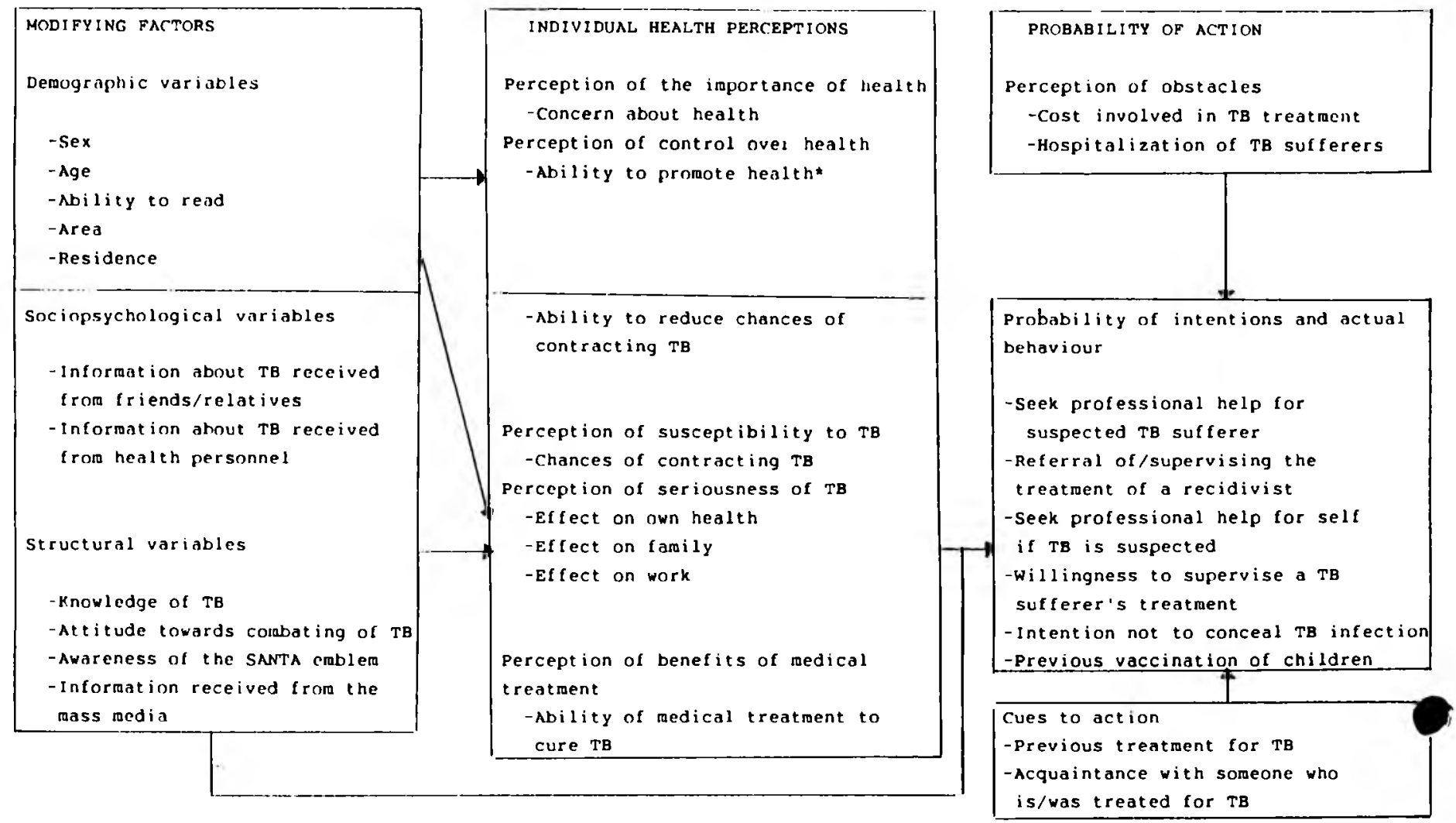

* Only the associations between the denographic variables and these two factors were tested since the sociopsychological and structural factors are specifically concerned with TB

\section{DISCUSSION}

\subsection{Individual health perceptions}

The perception of benefits of medical treatment is the perception that shows the most consequent associations in the expected direction with the independent variables. Factors such as knowledge of TB, a positive attitude towards the combating of $\mathrm{TB}$, the ability to read well, residence in an experimental area and awareness of the TB emblem, which show a positive association with this perception, all indicate a greater awareness of TB or a greater possibility of exposure to TBrelated information.

These factors, together with factors such as residence in an experimental area, receiving information from health personnel and receiving information from the mass media, indicate a greater degree of development than their opposites. Against this background it is interesting to note that both the ability to read well and receiving information from the mass media are positively associated with a greater perception of susceptibility to TB.

It is also worth noting that, in general, respondents with characteristics that indicate a higher level of development such as the ability to read well, urban residence, more knowledge and more positive attitudes towards the combating of TB had a more moderate view of the possible effect of TB on their own circumstances. Since TB is associated to some degree with certain socioeconomic situations such as malnutrition and overcrowding, it is possible that respondents with a higher level of development seldom come into contact with TB or its serious effects and therefore do not realize its seriousness. Respondents with a higher level of development also had a greater belief in the ability of medical treatment to cure TB completely. This may also cause them to regard the effects of TB in a less serious light.

Respondents with characteristics of a higher level of development, for instance, the ability to read well, were generally more concerned about their health. They also believed that they could promote their own health and could reduce their chances of contracting TB.

The conclusion can be made that respondents with a higher level of development, in comparison with the rest, accepted more responsibility for their health and believed that they had control over it and would therefore be less likely to view the possible effects of TB on their personal circumstances as serious.

Two further conclusions are rather distressing. Firstly, the negative associations between the receiving of information from friends/relatives and positive health perceptions indicate that information received in this way may in fact be harmful to the combating of TB. Secondly, the lack of positive associations between the receiving of information from health personnel and health perceptions indicate an inability of the health personnel to reach the general public with effective health messages.

\subsection{Prevention of TB and vaccination of} children

There were relatively few associations, mainly in the expected direction, between individual perceptions, perceptions of obstacles to action and cues to action on the one hand and intentions to combat TB and vaccination of children on the other. The most important role was played by the percep- tions of concem about health, control over health, benefits of medical treatment and obstacles in the way to treatment. The percep-tion of the seriousness of TB played a lesser role while the perception of susceptibility shows no associations with intentions or vaccination.

Previous studies (Langlie 1977:244 et sea. King 1982:1079 et seq.) also show positive associations between perceptions of control over health as well as concern about health and health behaviour. Other studies (Janz and Becker 1984) show that a perception of treatment as beneficial is a good predictor of preventive health behaviour. Perception of obstacles is also an important predictor while perception of seriousness is less so. However the perception of susceptibility was an important predictor in previous studies.

It is also important to note that the modifying factors and the individual perceptions show associations with intentions and vaccination which are independent of each other. The important direct association of modifying factors should therefore not be ignored.

The finding that more demographic and sociopsychological factors show associations with vaccination of children than with inten- 
tions may be due to the fact that vaccination of children was obligatory at the time of the survey, and that it was a well known method of combating TB while other preventive measures were less well known.

The negative association between the intention not to conceal a TB infection and the receiving of information from friends/relatives strengthens the supposition that information received in this way may not necessarily be creditable. The positive association between vaccination of children and the receiving of information from friends/relatives may be due to the fact that vaccination was generally accepted.

\section{CONCLUSION}

In conclusion the findings of this study has implications for health education. It highlights inter alia

the importance of a situation analysis before commencement of a health education programme to identify the target group and its characteristics;

the importance for health personnel of using the vaccination situation to convey information about the prevention of TB

the importance of fumishing the general public with correct information especially about susceptibility to TB and the benefits of medical treatment; the role that mass media can play in distributing the health message;

the necessity to incorporate people with characteristics of a higher level of development, for instance the ability to read well, into the preventive effort; and

the urgent need for community development.

\section{REFERENCES}

Becker, M. H. el al. 1975. Some influences on public participation in a genetic screening program. Journal of Community health, I(1) 3-14.

Fourie, P.B., TOWNSHEND, G.S. \& KLEEBERG, H.H. 1986. The importance of tuberculosis. In:

Fourie, P.B. \& TOWN-SHEND, G.S. (eds.) Current Views on Tuberculosis. Proceedings of the first TBRI Symposium held in Pretoria on 8 and 9 August 1985. South African Journal of Science, 82.

Galli, N. 1978. Foundations and Principles of Health Education: 175-219. New York Wiley.

Glatthaar, E. 1982. Tuberculosis control in South Africa. 'Where have we gone wrong?' and 'A look at the future'. South African Medical Journal, Special Edition

Gochman, D.S. 1972. The organizing role of motivation in health beliefs and intentions. Journal of Health and Social Behavior. 13:285-293.

King, Jennifer, B. 1982. The impact of patients' perceptions of high blood pressure on attendance at screening. Social Science Medicine, 16:1079-1091.

Langlie, Jean K. 1977. Social networks, health beliefs, and preventive health behavior. Journal of Health and Social Behavior, 18:244-266.

Pender, N.J. 1982. Health Promotion in Nursinq Practice. New Jersey: Appleton-CenturyCrofts, East Norwalk, Prentice Hall, Englewood Cliffs.
Rosenstock, I.M. 1966. Why people use health services. Milbank Memorial Fund Quaterly. 44:94-127

Steyn, M. 1988. 'n Ondersoek na die voorgenome handelinge van swartes om tuberkulose te bestry. University of the Orange Free State. (M.Soc.Sc. (Nursing) dissertation)

Acknowledgements

The authors wish to acknowledge the contributions of

1. members of the ad hoc-committee responsible for the planning of the project,

2. the staff of the Opinion Survey Centre, the Institute for Communication Research, the Institute for Statistical Research and ms. Ria Jouben in particular, and the Bureau for Suppor Services of the Human Sciences Research Council,

3. the Institute for Research Development of the Human Sciences Research Council for a gran enabling the first author to read this paper at the Sigma Theta Tau International 1989 Research Congress in Taiwan, R.O.C.

Steyn Mariana, M. Soc. Sc. Nursing, RN, RM, Dip. Paediatric Nursing. Dip. Clinical Care, Administration and Instruction, B.A. Honn (Soc.), Institute for Communication Research, Human Sciences Research Council

Viljoen Marlene, M.A. Cur. Professor Department of Nursing University of the Orange Free State

(Paper read at the Sigma Theta Tau International 1989 Research Congress Taipei Taiwan. Republic of China) 